\author{
Przemysław Ciszek \\ Uniwersytet Jana Kochanowskiego w Kielcach \\ ORCID: 0000-0003-0203-3810
}

\title{
Polish Thematic Media on Video Games 1990-2020
}

\begin{abstract}
This article presents the history and contemporary state of Polish media on the theme of video games. Media about video games emerged on the Polish market after the country's political transformation of 1989 and quickly became very popular. The ever increasing multitude of players led to demand for information and revieus on games. During 1990's there were many more or less significant magazines about video games in Poland. Almost all of them perished. Currently, there are only three of them on the Polish market. TV programmes about video games appeared during the 90s which effectively shoucased them in action. The media landscape has changed as the internet has become widely available and largely overtaken the information and entertainment function of the press and television in regards to video games. Today thematic websites about games are still important but youtubers and Twitch streamers are taking advantage. Their broadcast is especially important for younger generation of gamers. Presenting video games in action and live commentary is a very popular way of communication. Many online content creators have built great audience and income doing so.
\end{abstract}

Keywords: press, television, internet, video games, gamers.

Polskie media tematyczne o grach wideo w latach 1990-2020

\section{Streszczenie}

W artykule przedstawiono historię i uspółczesny stan polskich mediów na temat gier wideo. Media o grach wideo pojawiły się na polskim rynku po transformacji ustrojowej w 1989 roku i szybko stały się bardzo popularne. Coraz większa rzesza graczy potrzebowała informacji i recenzji gier. W latach dziewięćdziesiątych XX wieku istniało w Polsce wiele mniej lub bardziej znaczących magazynów poświęconych grom wideo. Prawie wszystkie zniknęły z rynku i obecnie istnieją tylko trzy. W latach dziewięćdziesiątych pojawiły się programy telewizyjne o grach wideo, które skutecznie prezentowały je w akcji. Krajobraz medialny zmienił się, gdy internet stał się pouszechnie dostępny i u dużej mierze wyprzedził funkcję informacyjną i rozrywkową prasy i telewizji u odniesieniu do gier wideo. Dziś strony internetoue poświęcone grom są nadal ważne, ale Youtuberzy i streamerzy na Twitch uykorzystują potencjał sieci jeszcze lepiej. Ich przekaz jest szczególnie ważny dla młodszego pokolenia graczy. Prezentowanie gier wideo w akcji i komentowanie na żywo to bardzo popularny sposób komunikacji. Wielu twórców treści online zyskało dzięki temu ogromną publiczność i dochody.

Słowa kluczowe: prasa, telewizja, internet, gry wideo, gracze. 


\section{Introduction}

Video games are a very important element of modern pop culture. Global video game revenue in 2020 has been estimated at nearly $\$ 180$ billion $^{1}$. This includes PC, console, and mobile gaming, as well as VR technology and esports. The fact that customers are able to buy almost any game physically or digitally has had a significant impact on the growing number of gamers. Due to the rapid development of esports, the number of people following the progress of the best players on the internet is growing steadily. Today, electronic games have become an important element of mass communication, reaching hundreds of millions of people all around the world.

Video game media consist of the press, TV and internet. The latter, due to its non-uniform structure, is the most complex communication channel on video games and provides diverse content. Gamers draw varied information from these forms of media - news, game previeus, revieus, journalism and other entertainment content.

The aim of this article is to present the current situation of the Polish gaming media market, as well as its changes. There has been no significant academic research on this topic so far, although the subject has been broached on gaming portals in the form of nostalgia pieces. The presented topic is a very broad issue, and this article is a cross-sectional and brief discussion of it ${ }^{2}$.

The main research method used in this study were media content analysis and internet queries. Thanks to many old internet pages and various discussion forums, it was possible to acquire information on out-of-print magazines and long-gone TV programmes. This allowed the author to recreate the history of video game media in Poland.

\section{Press}

Firstly, it is important to make a clear distinction between computer magazines and those relating to video games. The former have varying characteristics and are aimed either at a particular group of specialists or ordinary computer users. They do not deal with games as cultural products, but with technology. Video game magazines, on the other hand, are aimed at a wider group of potential readers, and while articles regarding broadly understood computer science can occasionally be found, they are popular and journalistic in nature.

The first thematic magazines about video games appeared in the early 80s in the USA and UK: 'Electronic Games' and 'Computer and Video Games'. During this period, game consoles appeared in millions of households, and gamers wanted the newest information on this subject.

\footnotetext{
${ }^{1}$ https://www.marketwatch.com/story/videogames-are-a-bigger-industry-than-sports-and-movies-combined-thanks-to-the-pandemic-11608654990 (accessed: 30.03.2021).

${ }^{2}$ A detailed presentation of Polish media about video games will be included in my upcoming book.
} 
Due to the socialist system governing Poland at the time, PCs and other electronic gaming devices were beyond the means of most citizens. ZX Spectrum and Commodore 64 could cost more than the average annual salary, and other consoles like NES were not available at all. It was a difficult time for video games in Poland. The first Polish text about video games appeared in 1985 in the computer magazine 'Bajtek', which devoted only a few pages to games in each issue, concentrating on more serious topics such as programming ${ }^{3}$.

In the Polish People's Republic, video games had a marginal presence in media, appearing merely as supplements in certain magazines on personal computers. The country's political transformation after 1989 meant that more and more Poles could afford to buy computers and game consoles. Electronic entertainment, formerly the domain of enthusiasts, has over the years become the 'daily bread' of millions, mainly young people.

The changes which took place in the Polish media market after 1989 brought in the rapid development of video game press, and many new titles emerged in the nineties. The main reason behind this was the growing number of computer users, and thus, gamers. Readers could find news, previeus, and revieus, as well as sought-after guides on how to complete games.

Initially, the founders of these magazines were small, often amateur publishers. Over time, western media giants entered the market and published Polish editions of their oun magazines (e.g. 'PC Gamer po Polsku') or took over already-existing titles ('CD-Action'). This period shaped the entire Polish commercial media market, including gaming magazines. Editors and authors had vast freedom in selecting their content and form, which sometimes resulted in specific humour and design.

The readers of these kinds of periodicals were mainly young people, their authors not much older. Very often, the core of the editorial office was made up of secondary school or university students who lacked basic journalistic skills and experience. They communicated with readers in the way they spoke themselves, which was in a colloquial and not very sophisticated manner. Today, publishers ensure high standards, and texts are no longer written in everyday, colloquial language - especially now that gaming press is addressed to more mature readers.

In the early nineties, a characteristic feature of Polish video game magazines was an emphasis not on reviewing games, but their description. Naturally, final evaluations were given; however the text itself was often advisory in nature, its premise to help players with the game. Over time, game descriptions turned into journalistic revieus with final mark (similar to e.g. movies revieus in dedicated magazines). This mark might be very important for readers, because it can influence their purchasing decisions. At the time game guides became a separate form of content. In addition, this type of press included many articles completely unrelated to video games, for example cultural columns regarding film or comics.

${ }_{3}^{3}$ http://zapach-papieru.pl/ (accessed: 30.03.2021). 
In the mid-nineties, some video game magazines came with covermounts: compact discs with game demos and programs. Later, full versions of games appeared in them as well. 'CD-Action' led this charge, supplementing every edition with several discs.

From 1990 to 2020, there were over 45 video game press titles on the Polish market. However, many of them were on the market for only a few months. The slow regression of this printed press segment started at the beginning of twentieth century $y^{4}$. Circulation and sales decreased. Due to the development and availability of the internet, gamers were able to find interesting - and more importantly - up to date information. Games became more and more popular, in part due to widespread piracy. The video game magazines which survived on the market had very similar content to those from the previous decade - with one main exception - over the years, gameplay advice and game cheats started to disappear from their pages, as gamers could find this information quicker online. Sections on topics unrelated to video games also lost their importance.

Currently, there are three video game magazines on the Polish market: 'CD-Action', 'PSX Extreme' and 'PIXEL'. 'CD-Action' is the oldest of the three and has been published since 1996. Its first publisher was small Wrocław publishing house Silver Shark. The title was later bought by the British company Future Network. Subsequently, in 2002, the magazine was taken over by the German Bauer Media Group. In mid2020, Bauer closed or sold some of its press titles in Poland and 'CD-Action' fell into the hands of the event company Fantasy Expo. The magazine has 13 issues per year, and contains information on games for all hardware platforms, focusing on games for PCs and stationary gaming consoles. There is no need to specialize as gamers often have both PCs and consoles, and most major games appear on all platforms. Every magazine issue is divided into three categories: 'Games', 'Technology' and 'Other'. For many years, 'CD-Action' also contained CDs/DVDs, but replaced them with scratch-off codes in autumn 2018. Since a new publisher took over the magazine in 2020, full versions of games are no longer given away.

'PSX Extreme' debuted in 1997. Initially, the magazine dealt only with games for PlayStation consoles (hence its title). However, over time it broadened its scope to include the other stationary consoles which were becoming more and more popular in Poland thanks to falling prices. The magazine was originally created by a group of friends who decided to break into the press market. Its first publishing house was Grupa 69, located in Katowice. In 2001, the magazine was taken over by the publishing house Advertigo. In 2019, Warsau company Idea Ahead (which already published the monthly magazine 'Pixel') became the new ouner and publisher of 'PSX Extreme'5.

This magazine also changed significantly over the years. The amount of news has noticeably fallen, whereas the number of journalistic articles and feuilletons has

\footnotetext{
${ }^{4}$ P. Ciszek, Czasopisma o grach wideo w Polsce. Rys historyczny i obecna sytuacja na rynku, „Rocznik Bibliologiczno-Prasoznawczy” 2016, vol. 8(19), s. 85-95.

${ }^{5}$ https://brief.pl/uydawca-pixel-magazine-kupuje-prawa-do-magazynu-psx-extreme/ (accessed: 30.03.2021).
} 
increased. Game guides, which were a permanent element in the 90's and early 21st century, were abandoned, as were games cheats which are generally available online.

'Pixel' is the newest title in this press segment. The history of its creation is connected to the reactivation of the magazine 'Secret Service', which happened thanks to a successful campaign on the croudfunding site polakpotrafi.pl. Unfortunately, due to legal reasons only two issues of the reactivated magazine were published. A large number of authors then moved to the newly-created 'Pixel'. The magazine offers similar content to that of its competitors - news, game previeus, revieus and journalistic articles - but a lot of attention is put on older games and the phenomenon of 'retrogaming'. 'Pixel's' subtitle - 'Kultura gier wideo' ('The Culture of Video Games') - is reflected in its content as many articles refer to games in a broad cultural context. Games for all platforms are reviewed and a lot of attention is given to indie games which are published without the participation of big publishing companies. 'Pixel' is published by Idea Ahead with 11 issues a year (they release a combined summer issue). During the several years of the magazine's existence, its content has not changed much. A lot of emphasis is placed on journalistic articles which sometimes take up more than half the volume of each issue.

The element which connects both past and present gaming magazines is the humour which appears in certain articles. Editors do not pretend to be serious and always bear in mind that they are creating entertainment magazines. Due to the aforementioned fact that the average age of their audience has increased, articles include references to history or pop culture which require some knowledge from the reader. Authors naturally adjust to new circumstances and do not treat readers as they did decades earlier.

Despite sharing the same theme, gaming magazines differ slightly from each other. This may be because readers find different types of content in every one of them. Thanks to this, all the magazines can successfully coexist on the market.

The language used by PC/console gamers is a distinct sociolect, full of terms unclear to outsiders. It mostly contains anglicisms (due to the fact that almost the whole 'gaming world' uses this language), Polish versions of foreign words (including English), as well as neologisms such as blend words from Polish and English used in the form of abbreviations. Individual groups of gamers have their oun vocabulary. Polish press discourse of this type, as in foreign magazines, is usually geared to entertainment and relaxation. After all, it deals with one of the most popular hobbies in the world. The language of the Polish press has changed considerably over the past two decades. The specific, colloquial language used by editors in the 90s would only be tolerated today on niche blogs or rather small, amateurish YouTube channels.

\section{Television}

Television seems to be the ideal medium to present electronic games, as they can be shown as they look on a computer screen. Fans are able to see the game in motion, rather than static screenshots in a magazine, and - importantly - can hear how it sounds. 
In Poland, video games made their first television appearance on the popular science program Sonda, broadcast on the public television channel 'TVP1' from 1977 to 1989. It was hosted by Zdzisław Kamiński and Andrzej Kurek, who presented the latest curiosities from the world of science and technology. One such novelty happened to be video games.

The nineties saw increased interest in video games, and TV stations did not ignore this phenomenon, providing audiences with information and entertainment programmes on the subject. 'Telewizja Polska' was a pioneer. The first typically computer-related programme on Polish television was Tele-radio-komputer which aired in September 1990. The title referred to the radio programme Radio-komputer broadcast on 'Polskie Radio'. In 1991 the title was changed to Telekomputer ${ }^{6}$. Video games appeared in it from time to time, but their presence was limited to short recordings of the game with voiceovers. Technical novelties remained the main focus of the programme.

A second programme, Joystick, showed real onscreen gaming. It was broadcast on every other Tuesday from 1993 to 2000. Its production staff included actors associated with TVP: Wojciech Malajkat and Kazimierz Kaczor? The programme consisted of several sections such as revieus, contests and live duels. During the latter, young team representatives gathered in-studio and competed against each other in various kinds of computer games, usually aiming to achieve the highest score. The rivalry was usually restricted to demonstrations of the onscreen character's movements in one setting for a couple of minutes. Many players saw each game for the first time and did not know the basic rules.

Another Polish video game programme worth mentioning is Escape, which appeared in 1996 on the channel Polonia 1. The originator was TV producer Konrad Kuiatkouski, who pitched the idea to the editorial board of the then-popular gaming magazine 'Top Secret's. The programme featured gameplays from the latest releases and voiceover by Tomasz Knapik, known from films and TV. Escape's advantages were its humour and professional production value. The programme was taken down in May 1998.

Multimedialny Odlot was another breakthrough in the history of Polish gaming television. It aired on the Polsat channel between 1997 and 1998 and was headed by Piotr Rubik and Monika Bral. Rubik chose games for the programme, and created its screenplays and soundtracks ${ }^{9}$. Gameplays with Rubik's background narration were the essence of the show. Topics discussed in the series concerned computer games, consoles and the internet.

'Game One/Hyper' was the only gaming TV channel, or programming block, on Polish television of its time. It debuted on 1st August 1999 and was connected

\footnotetext{
${ }^{6}$ http://sonda.astro4u.net/telekomp/1991.htm (accessed: 30.03.2021).

7 D. Michalski, Nie tylko Cywilizacja - wywiad z Kazimierzem Kaczorem, „Pixel” 2015, no. 7, pp. 78-81.

${ }^{8}$ https://www.eurogamer.pl/articles/2013-07-12-kulisy-poustania-i-upadku-programu-escape (accessed: 30.03.2021).

9 Specjalnie dla SS wywiad z twórcami programu „Multimedialny Odolt”, „Secret Service” 1997, no. 7-8, pp. 86-87.
} 
to the MiniMax channel available on satellite platform Cyfra+. In 2001, the block changed its name to Hyper; it existed until July 2014.

In the 21st century, Polish TV channels mainly broadcast informative programmes presenting announcements and new games. One of the last to survive was Allegra, which appeared on channel TV4 from 2009 to 2011.

Autumn 2018 saw the unexpected launch of the channel 'Polsat Games', a new addition to the family of Polsat channels, the largest television group in Central and Eastern Europe. Polsat Games is largely focused on the broadcast of electronic sports. It created esports organisation 'Ultraliga', which specialises in League of Legends tournaments. The channel's audience on traditional television is very small ${ }^{10}-$ far greater numbers watch the programmes and transmissions on its official YouTube and Twitch channels. Interestingly, 'Polsat Games' also broadcasts Japanese anime series.

In December 2018 a rival of Polsat Games appeared: GameToon, part of SPI International. The company Kino Polska TV, whose offerings also include film channels, is responsible for its broadcasts in Poland. GameToon also spends a lot of airtime on esports. It is mainly available through cable operators and online. Polsat Games and GameToon are linked by their focus on esports news and gaming.

Television is a great platform for conveying information about video games, but it seems to have lost in competition with the internet. Polish gaming programmes had their glory days in the 90 's and at the beginning of the 21st century. As their only competition at the time came from gaming magazines and simple internet sites based on text and screenshots, such channels had a good reason for being. Typically they presented new games revieus, announcements and neus. A separate segment included programmes on which the audience played the games via telephone. The decline in popularity of television programmes related to video games overlaps with the emergence of platforms like YouTube, which became the main method of uploading videos on the internet.

\section{Internet}

In an online environment, the 'creator-recipient' roles are no longer as clearly defined and adhered to as they were in old media. Division into producers/consumers, professionals/amateurs is relative; their functions are intertwined, creating a specific conglomerate of media roles. This situation is perfectly illustrated by the video game media market. Every gamer, if they so wish, is able to comment online through blogs, vlogs or podcasts. It is impossible to present all this various aspects in a short article, so I will concentrate on most important of them - big portals and youtubers/Twitch streamers.

${ }^{10}$ https://www.wirtualnemedia.pl/artykul/1-4-tys-widzow-kanalu-polsat-games-animacja-dragon-ball-super-hitem-interesujace-tresci-dla-pewnej-niszy-odbiorcou (accessed: 30.03.2021). 
The internet has changed the situation in the gaming magazine industry and became its serious competitor, especially when it comes to up-to-date information. Initially, official websites reigned almost exclusively over the Polish internet, run by professional journalists (usually those who had edited formerly printed magazines). Amateur internet pages were rare back then, however, over time this started to change. While professional journalists and editors of magazines or online websites had an advantage over amateurs in regards to access to news (thanks to their industry connections) as well as new games for testing, game reviews and news could appear on amateur websites without hindrance. The next step was online sites which, thanks to the lack of publishing cycle constraints, had the advantages of providing up-to-date information, as well as free and easy access. At first, revieus and other press materials were published in a similar form as in magazines, i.e. text and screenshots from any given game. Over time, however, thanks to technical developments and increased connection speed, they were enhanced by films presenting gameplays which better reflect the character of the game and are more attractive to viewers.

Due to the variety of online content regarding video games, it is necessary to divide it into several groups: typical, organised information websites (specifically equivalents to printed gaming magazines); private blogs; video content - concentrated on YouTube and similar platforms.

The most important Polish-language video game online portals are: Gry-OnLine (www.gry-online.pl), Gram.pl (www.gram.pl), Polygamia (www.polygamia.pl) and Eurogamer (wuw.eurogamer.pl). The table below shows a list of the main Polish video gaming-related pages, compiled using rankings from services SimilarWeb and Alexa. The former provides a separate score for Poland.

Table 1. Ranking of the most popular video game websites in Poland (March 2021)

\begin{tabular}{|l|c|c|}
\hline & SimilarWeb (Poland) & Alexa (Global) \\
\hline Gry-online & 117 & 9,379 \\
\hline PPE.pl & 440 & 41,646 \\
\hline Eurogamer.pl & 709 & 94,209 \\
\hline Cdaction.pl & 1,339 & 18,961 \\
\hline Gram.pl & 1,463 & 87,366 \\
\hline Polygamia.pl & 1,828 & 231,496 \\
\hline Planetagracza.pl & 3,844 & 317,499 \\
\hline
\end{tabular}

Source: own research.

The latest available data regarding the number of monthly active users are from December 2019. According to which the leader is Gry-online.pl with 2.252,000 users, followed by Eurogamer.pl $(989,000)$, then PPE.pl $(738,000)^{11}$.

Beside these there are many other smaller and less popular websites with varying degrees of professionalism. Private blogs usually have a small number of views - although

${ }^{11}$ https://www.wirtualnemedia.pl/artykul/gry-online-pl-na-czele-steamcommunity-przed-epicgames-a-twitch-przed-ppe-pl-top10-serwisow-o-grach (accessed: 30.03.2021). 
the only available popularity indicator may be the number of likes on their Facebook fanpages.

Podcasts have also begun to appear online (game-related audio broadcasts). They play a significantly smaller role than written media, and it is hard to establish their significance to the gaming community.

The creation of YouTube in 2005 was a milestone in the development of gaming-focused media, and it very quickly became the leading online video platform. However, it would never have existed if not for the spread of broadband internet access throughout both developed and developing countries. As an audiovisual medium, video games are ideal for presenting in the form of recordings and uploading on to platforms like YouTube. This has resulted in the creation of many channels whose authors publish revieus, opinions, or simply recorded gameplay with commentaries (or sometimes without).

Several basic types of content about video games can be distinguished on global and also Polish YouTube:

- let's play;

- news;

- entertainment;

- guides.

Video materials on electronic games are very diverse. Let's play videos is an important genre which allows the audience to clearly see for themselves what the game looks like. Many videos adopt a guide form and aim to help viewers understand the rules of a given game or pass its more difficult stages. For several years we have been dealing with the so-called 'youtubification' of video games ${ }^{12}$. Games seem to fit YouTube like no other medium and with every year more and more creators are making new channels. Of course most of them will concentrate on simple content as mentioned earlier let's play videos. More sophisticated and ambitious materials such as game revieus or documentary about the history of video games are usually domain of more professional youtubers who treat this activity as a source of income. Presentation style largely depends on the type of material as well as the individual style of the content creator. The most-subscribed Polish gaming YouTuber - Szymon 'Isamu' Kasprzyk - has over 2.5 million subscribers so far. He is concentrating on Counter-Strike: GO and other competitive e-sports games. He also publishes let's play videos and very popular in recent years 'reaction' videos.

In general polish gaming YouTubers do not currently deviate from their foreign counterparts when it comes to content. Certainly, to some extent they take inspiration from the most popular foreign creators, for example, they use similar outlines for creating video thumbnails. After studying the background of today's most popular YouTube gamers, we can see that many of them started with completely amateur Minecraft videos.

${ }_{12}$ W. Sosnouski, Dwa aspekty „youtubifikacji” gier video - analiza wybranych przykładów nowego zjawiska w branży gier wideo, „Homo Ludens” 2017, no. 1, pp. 239-252. 
Ten of the most popular Polish gaming Youtubers have a total of about 18.8 million subscribers. They most frequently upload let's play videos, Minecraft being the most popular.

The next step which helped to develop this media was game streaming to live audiences online, thanks to which thousands of people are able to watch live-streamed games and interact with players via online chats. The main platform which enables this is Twitch.tv which is used by the majority of the most popular streamers. For many gamers, live game streaming was another feature which made Twitch supersede other ways of finding information about their hobby.

Video game live streaming is a phenomenon that has gained significance in recent years. Communication during streaming is multi-channel, both visual and audio. The broadcaster communicates with viewers by voice and the accompanying live chat. In turn, viewers comment on the online chat and also, if the broadcaster enables such an option, through paid-for messages.

The most popular Twitch streamers often come from the esports circle. Piotr 'Izak' Skouyrski - a former esports player specialising in Counter-Strike $G O$ - has his own channel IzakOOO and over 1.5 million followers. Marcin 'xayoo_' Majkut is next in line when it comes to number of followers (over 700,000). Kamil 'ewroon' Lachouski has the third-highest follower base (over 670,000) and is known for streaming Fortnite gameplays.

For top streamers, this activity has become a way of life, and to earn money, which they get from viewers and sponsors. Their work is not very informative, focusing instead on the entertainment side of video games. Viewers can see what the game looks like and how it is played.

Thanks to the internet, anyone can gather information on emerging games and publish their own announcement trailers on blogs, podcasts or YouTube. Unfortunately, there are also some negative aspects to this democratisation of media. In the press and large internet portals there are paid, properly educated professionals who oversee content and language quality, whereas the audience of amateur or semi-amateur works cannot be sure whether the content they are consuming is correct in every aspect. Here, trust in the author of the text or video plays an important role. Prior to the prevalence of internet videos, the main source of information for gamers/internet users were thematic internet platforms and smaller websites edited by amateurs. The current expansion of video materials made ordinary articles enhanced with graphics lose their appeal.

YouTube and Twitch have changed the way in which gamers in Poland, and around the world, find information about their favourite games. They no longer have to wait for a monthly gaming magazine to be published, or look to websites where the content was presented in the same way as in the press, i.e. text and static pictures. Every fan can watch their game of choice 'in motion' thanks to the thousands of people who upload let's play recordings or live-stream their gaming sessions. 
Nowadays, traditional journalists have to coexist with amateurs and influencers in the internet gaming world. They lost their monopoly on informing about games and reviewing them - it can be said that this segment has been democratised. There is nothing to suggest that this trend will reverse. We are, therefore, dealing with the cult of the amateur ${ }^{13}$, enabling ordinary people to publish game-related content. This resembles the early ' 90 s, when the editors of gaming magazines were young people who, de facto, were amateurs/game fans.

Two primary functions of gaming media can be distinguished - information and entertainment. The former is largely the domain of press and internet journalists. YouTubers combine both of these functions, although there are some who specialize exclusively in entertainment materials.

\section{Conclusion}

Video game-related media in Poland undergoes constant evolution following global trends. This is a necessity, as the worlduide media of today is becoming increasingly unified and digitalised. The changes in this media segment are often very dynamic, especially in the case of the internet. The global trend of the gradual decline in significance of print media is especially visible in the gaming industry. In Poland, there are currently only three press titles in this segment and their sales numbers are not very impressive, particularly when compared to figures from the beginning of the 21st century. The number of news articles unrelated to games or computers has increased significantly. This is due to the fact that revieus are easily accessible on gaming websites. Young people watch less and less television, so existing video game-related TV channels are not geared towards traditional viewers sitting in front of the TV. Instead, these programmes have their audience in the internet, i.e. the natural space for most gamers. We can assume that the role of the internet will be even greater in the future, and that the most important element in gaming media will be live streams and other video materials. They are easier to process than written text and their information and entertainment value is often much greater.

\section{References}

Ciszek P., Czasopisma o grach wideo w Polsce. Rys historyczny i obecna sytuacja na rynku, „Rocznik Bibliologiczno-Prasoznawczy” 2016, vol. 8(19), pp. 85-95.

Florek A., Wydawca Pixel Magazine kupuje prawa do magazynu PSX Extreme. Available online: https://brief.pl/uydawca-pixel-magazine-kupuje-prawa-do-magazynu-psx-extreme/ (accessed: 30.03.2021).

http://sonda.astro4u.net/telekomp/1991.htm (accessed: 30.03.2021).

http://zapach-papieru.pl/ (accessed: 30.03.2021).

${ }^{13}$ See: Andrew Keen, The Cult of the Amateur, Crown Publishing Group, New York 2007. 


\section{Przemysław Ciszek}

Jankouski, Z., Kulisy powstania i upadku programu Escape. Available online: https://www. eurogamer.pl/articles/2013-07-12-kulisy-poustania-i-upadku-programu-escape (accessed: 30.03.2021).

Keen A., The Cult of the Amateur, Crown Publishing Group, New York 2007.

Michalski D., Nie tylko Cywilizacja - wywiad z Kazimierzem Kaczorem, „Pixel” 2015, no. 7, pp. 78-81.

Sosnouski W., Dwa aspekty „youtubifikacji” gier video - analiza wybranych przykładów nowego zjawiska w branży gier wideo, „Homo Ludens” 2017, no. 1, pp. 239-252.

Specjalnie dla SS wywiad z twórcami programu „Multimedialny Odlot”, „Secret Service” 1997, no. 7-8, pp. 86-87.

Wirtualnemedia.pl, Gry-online.pl na czele, Steamcommunity przed Epicgames, a Twitch przed PPE.pl (TOP10 serwisów o grach). Available online: https://www.wirtualnemedia.pl/ artykul/1-4-tys-widzow-kanalu-polsat-games-animacja-dragon-ball-super-hitem-interesujace-tresci-dla-pewnej-niszy-odbiorcou (accessed: 30.03.2021).

Wirtualnemedia.pl, Gry-online.pl na czele, Steamcommunity przed Epicgames, a Twitch przed PPE.pl (TOP10 serwisów o grach). Available online: https://www.wirtualnemedia. $\mathrm{pl} /$ artykul/gry-online-pl-na-czele-steamcommunity-przed-epicgames-a-twitch-przed-ppe-pl-top10-serwisou-o-grach (accessed: 30.03.2021).

Witkouski W., Videogames are a bigger industry than movies and North American sports combined, thanks to the pandemic. Available online: https://www.marketwatch.com/ story/videogames-are-a-bigger-industry-than-sports-and-movies-combined-thanks-to-the-pandemic-11608654990 (accessed: 30.03.2021). 